\title{
A Novel PTCH1 Frameshift Mutation Leading to Nevoid Basal Cell Carcinoma Syndrome
}

DOI:

$10.1159 / 000487747$

Document Version

Accepted author manuscript

Link to publication record in Manchester Research Explorer

\section{Citation for published version (APA):}

Durmaz, C. D., Evans, D. G., Smith, M. J., Ertop, P., \& Akay, B. N. (2018). A Novel PTCH1 Frameshift Mutation Leading to Nevoid Basal Cell Carcinoma Syndrome. Cytogenetic and Genome Research.

https://doi.org/10.1159/000487747

\section{Published in:}

Cytogenetic and Genome Research

\section{Citing this paper}

Please note that where the full-text provided on Manchester Research Explorer is the Author Accepted Manuscript or Proof version this may differ from the final Published version. If citing, it is advised that you check and use the publisher's definitive version.

\section{General rights}

Copyright and moral rights for the publications made accessible in the Research Explorer are retained by the authors and/or other copyright owners and it is a condition of accessing publications that users recognise and abide by the legal requirements associated with these rights.

\section{Takedown policy}

If you believe that this document breaches copyright please refer to the University of Manchester's Takedown Procedures [http://man.ac.uk/04Y6Bo] or contact uml.scholarlycommunications@manchester.ac.uk providing relevant details, so we can investigate your claim.

\section{OPEN ACCESS}




\section{A novel PTCH1 frameshift mutation leading to Nevoid basal-cell carcinoma syndrome}

Ceren Damla Durmaz ${ }^{1}$, Gareth Evans ${ }^{2,3}$, Miriam J. Smith ${ }^{2,3}$, Pelin Ertop ${ }^{4}$, Bengü Nisa Akay ${ }^{4}$, Timur Tuncal1 ${ }^{1}$

${ }^{1}$ Department of Medical Genetics, Faculty of Medicine, Ankara University, Ankara, Turkey

${ }^{2}$ Division of Evolution and Genomic Science, School of Biological Sciences, Faculty of Biology, Medicine and Health, University of Manchester, Manchester Academic Health Science Centre, Manchester, UK.

${ }^{3}$ Manchester Centre for Genomic Medicine, St Mary's Hospital, Central Manchester University Hospitals NHS Foundation Trust, Manchester Academic Health Science Centre, Manchester, UK

${ }^{4}$ Department of Dermatology, Faculty of Medicine, Ankara University, Ankara, Turkey

Correspondence to: Ceren Damla Durmaz MD

E-mail: $\underline{\text { durmaz@ankara.edu.tr }}$

Postal address: Ankara Üniversitesi Tıp Fakültesi, Tıbbi Genetik AD, Dekanlık Binası, 06100, Ankara, Türkiye

Phone number: 00903125958163

Fax number: 00903123100091

\section{Key words}

Nevoid basal-cell carcinoma syndrome, Gorlin Syndrome, PTCH1, SUFU, medulloblastoma

Running head: A Gorlin Syndrome case with a novel mutation in PTCHIgene. 


\begin{abstract}
Nevoid basal-cell carcinoma syndrome (NBCCS) also known as Gorlin syndrome is a rare, multisystemic, autosomal dominant condition typically presenting with cutaneous basal cell carcinomas, multiple keratocysts, and skeletal anomalies. NBCCS is caused by heterozygous mutations in the PTCH1 gene on chromosome 9q22, the PTCH2 gene on 1p34, or the $S U F U$ gene on 10q24.32. Here, we report on an 18-month-old boy with medulloblastoma, frontal bossing and multiple skeletal anomalies and his father who has basal cell carcinomas, palmar pits, macrocephaly, bifid ribs, calcification of falx cerebri and history of surgery for odontogenic keratocyst. These clinical findings were compatible with the diagnosis of NBCCS, and a novel mutation, c.1249delC; p.Gln417Lysfs*15 was found in PTCH1 gene causing a premature stop codon.
\end{abstract}




\section{Introduction}

Nevoid basal-cell carcinoma syndrome (NBCCS, OMIM: 109400) is an uncommon, autosomal dominant condition with multisystem involvement caused by mutations in the PTCH1, PTCH2 or SUFU gene. The characteristic features of the disorder are skin manifestations, jaw keratocysts, lamellar (sheet-like) calcification of the falx, childhood medulloblastoma, macrocephaly, ovarian/cardiac fibromas and skeletal anomalies such as vertebral/rib anomalies and preaxial or postaxial polydactyly (Evans and Farndon 1993). Ocular anomalies seen in some cases include strabismus, congenital cataract, eyelid cysts, myelinated nerve fibers and pigmentary changes of the retinal epithel (Chen et al. 2015).

Skin manifestations of NBCCS include multiple and early onset basal cell carcinomas (BCC), milia, epidermoid cysts, chalazia, comedones, and palmar and plantar pits (Gorlin 1987). Basal cell carcinomas can be observed early childhood but mostly present in early adulthood. There is increased risk of BCC in whole body including vulva and perianal region (Giuliani et al. 2005), (Wang and Goldberg 2007). Hence, both increased frequency of BCCs on sunexposed areas such as the scalp, face, neck, chest and back and less BCC occurrence in darker skin phenotypes support that ultraviolet exposure contributes to the cancer risk in this syndrome (Kulkarni et al. 2003). These BCCs are histologically similar to the ones that observed in non-NBCCS patients. Clinical diagnosis of NBCCS is based on the presence of two major criteria or one major and two minor criteria (Jones et al. 2011).

PTCH1, mapped to $9 \mathrm{q} 22$, is one of the genes known to cause this phenotype. PTCH1 is a tumor suppressor gene consists of 23 exons, encodes the protein patched homolog 1 which plays a significant role in hedgehog signaling pathway that is extremely important for embryonic development (Gorlin 2004). On the other hand, PTCH2 is located at 1p34 and is highly homologous to PTCH1. This gene encodes the protein patched homolog 2 which 
functions as a tumor suppressor in the hedgehog signaling pathway (Cohen Jr 2010). In addition, $S U F U$ gene mutations are also responsible for this syndrome. $S U F U$ was mapped to 10q24.32, and encodes the suppressor of a fused homolog protein that is a negative regulator of the hedgehog signaling pathway (Evans and Farndon 1993). While most of the NBCCS patients bear pathogenic variants in PTCH1 gene, SUFU mutations are less common. PTCH2 pathogenic variants were found mostly in sporadic basal cell carcinoma and medulloblastoma patients somatically except in a Chinese Han family with NBCCS which have germline mutation (Fan et al. 2008). The genotype-phenotype correlation is difficult to establish for NBCCS. Patients with SUFU mutation were significantly more likely than those with PTCH1 mutations to develop a medulloblastoma, however were less likely to develop an odontogenic keratocysts (Evans et al. 2017).

Here, we present an 18-month-old boy with medulloblastoma, multiple congenital anomalies and his father who has basal cell carcinomas, skeletal anomalies and was operated for odontogenic keratocyst with a novel, frameshift mutation in $\mathrm{PTCH} 1$ gene.

\section{Clinical Report}

The patient was born at term by cesarean section with a birth weight of $4,080 \mathrm{~g}$. He is the second child of non-consanguineous parents and he has a seven-year-old brother who has learning difficulties. He was referred to us because of his history of surgery for classic type medulloblastoma that was confirmed histopathologically, various skeletal anomalies and multiple congenital malformations. Clinical examination showed macrocephaly (OFC >97p), frontal bossing, coarse face, broad nasal bridge, short neck, postaxial polydactyly of left hand and right foot and left cryptorchidism. He had visual and hearing loss and also impaired swallowing due to medulloblastoma operation. He was $78 \mathrm{~cm}$ tall $\left(10-25^{\text {th }}\right.$ percentile), weighted $10 \mathrm{~kg}\left(25-50^{\text {th }}\right.$ percentile $)$ with a head circumference of $52 \mathrm{~cm}\left(97^{\text {th }}\right.$ percentile $)$. His 
abdominal ultrasonography proved to be normal. However, X-ray examinations revealed fused ribs and vertebrae. Esophagogram showed gastroesophageal reflux and his karyotype was $46, \mathrm{XY}$.

His father had macrocephaly, pectus carinatum, pes cavus and history of surgeries for recurrent odontogenic keratocyst. On dermatological examination, histopathologically confirmed three basal cell carcinomas on head, neck and chest region were observed. Histologically, two of them that are on neck and chest region are nodular BCCs, whereas the other is multifocal and superficial BCC. Total excision with safe surgical margins was chosen for treatment. Also, he had bilateral palmar pits. Radiological examinations showed bifid rib anomalies and calcification of falx cerebri. These findings suggested NBCCS (Table). To prove the diagnosis we performed molecular genetic testing for NBCCS.

\section{Methods and Results}

Genomic DNA was isolated from peripheral blood samples of the proband, his brother and their father using MagnaPure LC DNA Isolation Kit-Large Volume and MagnaPure LC instrument (Roche Applied Science, Mannheim, Germany). Each of the 12 SUFU coding exons and each of the 23 PTCH1 coding exons, including flanking intronic regions, were amplified by PCR using GoTaq G2 2x MasterMix or GoTaq G2 HotStart 2x MasterMix (Promega, Southampton, UK). Products were purified using AxyPrep Mag PCR clean up beads (Appleton Woods, Birmingham, UK). DNA sequencing was performed using BigDye® Terminator v3.1 Cycle Sequencing Kit (ABI, Life Technologies, USA). Sequencing PCR products were purified using AxyPrep Mag Dye Clean beads (Appleton Woods, Birmingham, UK) and sequence analysis was performed using the ABI 3730xl DNA Analyzer (ABI, Life Technologies, Paisley, UK). 
We found a novel heterozygous c.1249delC; p.Gln417Lysfs*15 mutation in PTCH1 gene in the patient and his father whereas his brother was found wild type (Figure 3). This variant was not listed in the 1000 Genomes (http://browser.1000genomes.org/index.html) nor in the ExAC database (http://exac.broadinstitute.org/). However, a nonsense mutation $(\mathrm{c} .1249 \mathrm{C}>\mathrm{T})$ at the same base is listed in the Catalogue of Somatic Mutations in Cancer database (COSMIC) in a skin tumor. The impact of the frameshift mutation on protein patched homolog 1 structure and function predicted by in silico analysis was described as damaging. This frameshift mutation causes premature stop codon that may cause a nonsensemediated decay.

\section{Discussion}

Here we describe a familial NBCCS case with medulloblastoma emerging from a novel frameshift mutation in PTCH1 gene. About 5\% of the patients with NBCCS develop medulloblastoma that typically occurs during the first two years of life, unlike the sporadic forms in which the peak incidence is at seven years (Cowan et al. 1997) (Amlashi et al. 2003). The risk for medulloblastoma is up to $33 \%$ in SUFU-related NBSSC cases. Whereas in PTCH1-related NBCCS patients, the risk for medulloblastoma is lower than 2\%. (Smith et al. 2014). In NBCCS, medulloblastoma tends to be of desmoplastic histology, but interestingly, our patient's medulloblastoma was classic histopathologic type.

PTCHI is a member of Patched family encoding protein patched homolog 1 that acts as a receptor for hedgehog signaling pathway. The Hedgehog signaling pathway is involved in many physiological processes, especially morphogenesis, during the embryonic development. Patched family proteins act as receptors for this signaling pathway (Cohen Jr 2010). In the absence of its ligand, Sonic Hedgehog, PTCH1 suppresses the release of another protein 
called Smoothened. When sonic hedgehog binds PTCH1, Smoothened releases and initiates a target gene transcription through transcription factors (Nachtergaele et al. 2013).

PTCH1 is also a tumor suppressor gene. According to Knudson's two hit hypotheses, the first mutation is inherited (germline). The second hit - due to any random somatic events - can lead to cancer (Knudson 1971). In NBCCS, the first (germline) mutation is responsible for the dysmorphologic features and the skeletal anomalies. The second hit accounts for a loss of heterozygosity and causes tumors such as BCC, medulloblastoma, odontogenic keratocyst. PTCH1 gene mutations have been also identified in some sporadic cancers such as isolated BCCs, medulloblastoma, meningioma and breast cancer etc. (Cohen 2003).

Nonsense, missense, frameshift, splice site mutations and large-scale deletions or rearrangements of the PTCHI gene were identified in NBCCS (Evans and Farndon 1993). However, as the novel variant that we identified in our cases most of the NBCCS causing mutations are frameshift type leading to premature termination codons.

NBCCS shows intra- and interfamilial variation in expression hence, diagnosis can be challenging. In particular, medulloblastoma cases under 2 years of age may be remarkable for the diagnosis of NBCCS. Herein, we identified a novel, frameshift mutation in exon 9 of the PTCH1 gene in a NBCCS case with medulloblastoma and his affected father. This frameshift mutation causes premature stop codon and is responsible for the clinical features.

\section{Acknowledgments}

The authors would like to thank the patient and her family for their collaboration. 


\section{References}

1) Amlashi SF, Riffaud L, Brassier G, Morandi X: Nevoid basal cell carcinoma syndrome: relation with desmoplastic medulloblastoma in infancy. Cancer 98:618-624 (2003).

2) Chen JJ, Sartori J, Aakalu VK, Setabutr P: Review of ocular manifestations of nevoid basal cell carcinoma syndrome: What an ophthalmologist needs to know. Middle East African journal of ophthalmology 22:421 (2015).

3) Cohen Jr MM: Hedgehog signaling update. American Journal of Medical Genetics Part A 152:1875-1914 (2010).

4) Cohen MM: The hedgehog signaling network. American Journal of Medical Genetics Part A $123: 5-28(2003)$.

5) Cowan R, Hoban P, Kelsey A, Birch JM, Gattamaneni R, Evans D: The gene for the naevoid basal cell carcinoma syndrome acts as a tumour-suppressor gene in medulloblastoma. British journal of cancer 76:141 (1997).

6) Evans DG, Farndon PA: Nevoid Basal Cell Carcinoma Syndrome, in Pagon RA, Adam MP, Ardinger HH, Wallace SE, Amemiya A, Bean LJH, Bird TD, Ledbetter N, Mefford HC, Smith RJH, Stephens K (eds): GeneReviews(R)Seattle (WA) 1993).

7) Evans DG, Oudit D, Smith MJ, Rutkowski D, Allan E, Newman WG, Lear JT: First evidence of genotype-phenotype correlations in Gorlin syndrome. Journal of Medical Genetics:jmedgenet-2017-104669 (2017).

8) Fan Z, Li J, Du J, Zhang H, Shen Y, Wang C-Y, Wang S: A missense mutation in PTCH2 underlies dominantly inherited NBCCS in a Chinese family. Journal of medical genetics 45:303-308 (2008).

9) Giuliani M, Di Stefano L, Zoccali G, Angelone E, Leocata P, Mascaretti G: Gorlin syndrome associated with basal cell carcinoma of the vulva: A case report. European journal of gynaecological oncology 27:519-522 (2005). 
10) Gorlin RJ: Nevoid basal-cell carcinoma syndrome. Medicine 66:98-113 (1987).

11) Gorlin RJ: Nevoid basal cell carcinoma (Gorlin) syndrome. Genetics in Medicine 6:530539 (2004).

12) Jones EA, Sajid MI, Shenton A, Evans DG: Basal cell carcinomas in gorlin syndrome: a review of 202 patients. Journal of skin cancer 2011 (2011).

13) Knudson AG: Mutation and cancer: statistical study of retinoblastoma. Proceedings of the National Academy of Sciences 68:820-823 (1971).

14) Kulkarni P, Brashear R, Chuang T-Y: Nevoid basal cell carcinoma syndrome in a person with dark skin. Journal of the American Academy of Dermatology 49:332-335 (2003).

15) Nachtergaele S, Whalen DM, Mydock LK, Zhao Z, Malinauskas T, Krishnan K, Ingham PW, Covey DF, Siebold C, Rohatgi R: Structure and function of the Smoothened extracellular domain in vertebrate Hedgehog signaling. Elife 2:e01340 (2013).

16) Smith MJ, Beetz C, Williams SG, Bhaskar SS, O'Sullivan J, Anderson B, Daly SB, Urquhart JE, Bholah Z, Oudit D: Germline mutations in SUFU cause Gorlin syndromeassociated childhood medulloblastoma and redefine the risk associated with PTCH1 mutations. Journal of Clinical Oncology 32:4155-4161 (2014).

17) Wang SQ, Goldberg LH: Multiple polypoid basal cell carcinomas on the perineum of a patient with basal cell nevus syndrome. Journal of the American Academy of Dermatology 57:S36-S37 (2007) 


\section{Figure Legends}

Fig.1a: Frontal picture of the proband. Note frontal bossing, coarse face and broad nasal bridge.

Fig.1b: Photographs of patient's left hand with postaxial polydactyly.

Fig.1c: Chest X-ray image shows fused ribs.

Fig.1d: Cranial MRI shows posterior fossa tumor.

Fig.2a: Dermatoscopic image of a partly pigmented, smooth papule located on the neck. Arborizing telangiectasias are visible, along with multiple blue-gray globules, white clods and central ulceration. Histopathology confirmed the diagnosis of nodular BCC.

Fig.2b: Palmar pits on his right hand.

Fig.2c: Photograph of patient's back. Note asymmetrical appearance due to skeletal malformations.

Fig.2d: Photograph of right side view of the patient. Note chest deformity.

Fig.3: Electropherograms of the patient and his father show a heterozygous frameshift mutation (c.1249delC; p.Gln417Lysfs*15) in PTCH1.

\section{Table Legend}

Table: Comparation of diagnostic criteria for Nevoid basal-cell carcinoma syndrome with our patients' clinical features. Proband is deceased at the age of 2 after medulloblastoma surgery. Hence, some of his clinical features hadn't appeared at that time. 
Figure 1.
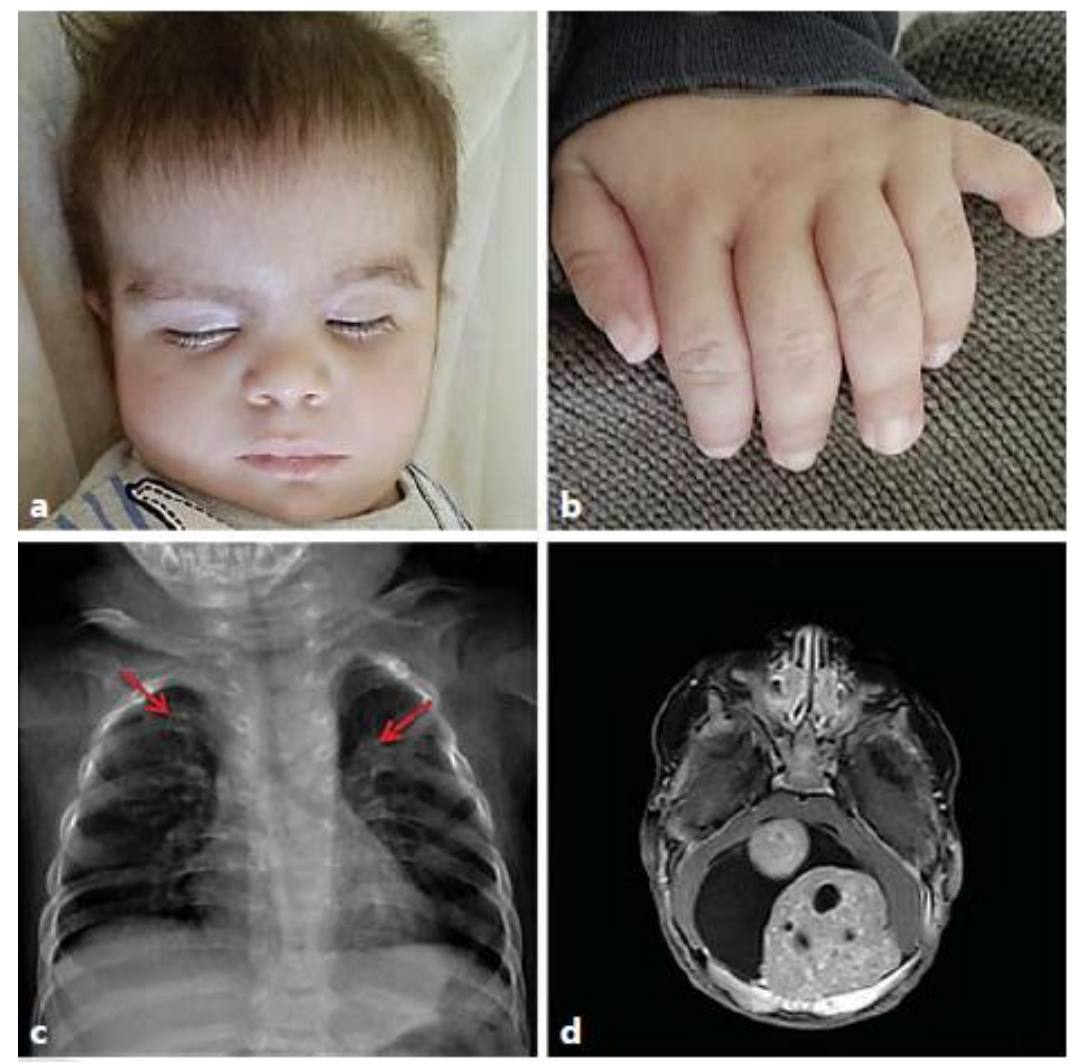

Figure 2.

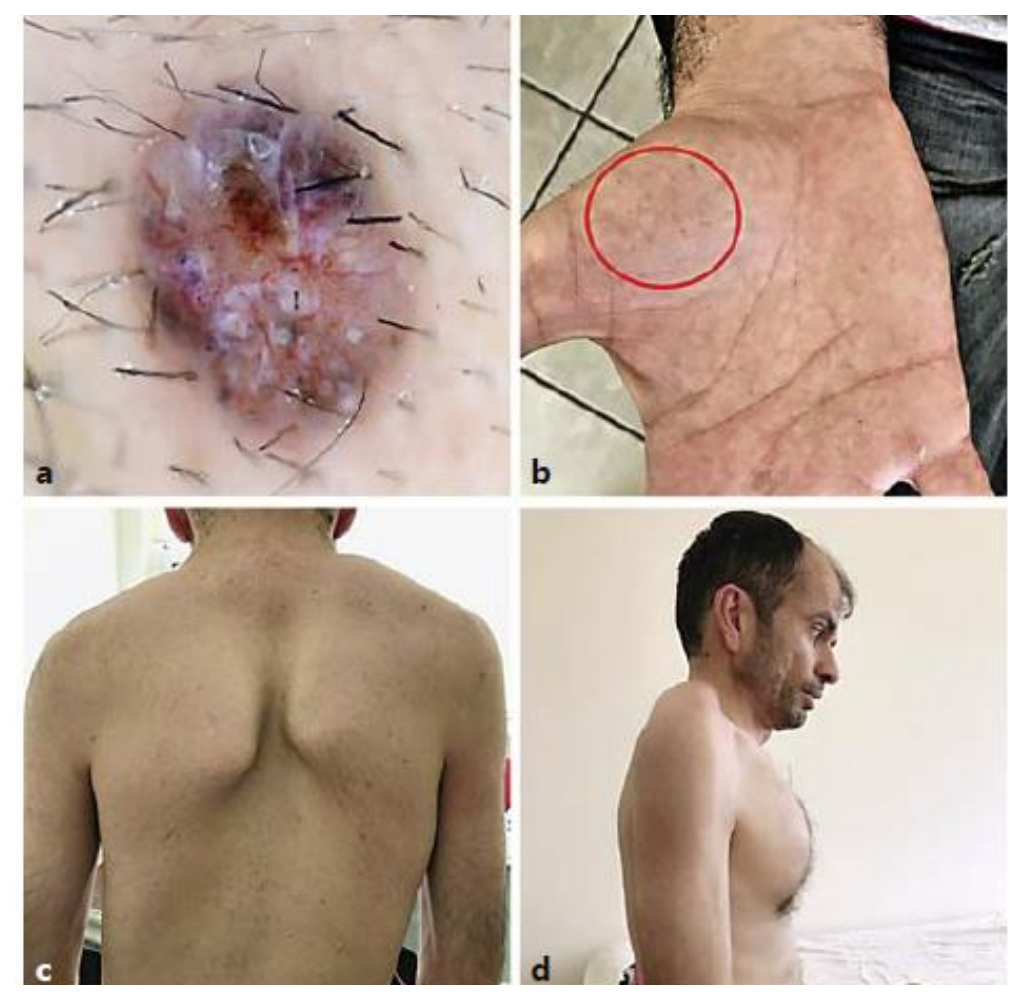


Figure 3.

PTCH1; c.1249delC; p.Gln417Lysfs*15
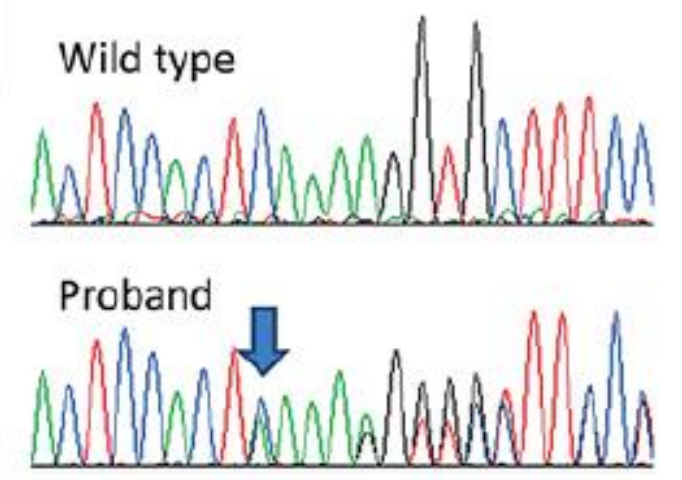

\section{Father}

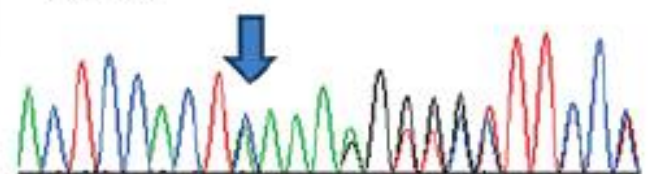


Table 1.

\begin{tabular}{lll}
\hline & Proband & Father \\
\hline Major criteria & & 3 BCCs at 36 years \\
Multiple ( $>$ in a lifetime) BCCs, or a BCC before age 30 years & $?$ & + \\
Odontogenic keratocysts proven by histology & $?$ & + \\
Palmar/plantar pits (2 or more) & $?$ & + \\
Lamellar (sheet-like) calcification of the falx & - & - \\
First-degree relative with NBCCS & + & + \\
Minor criteria & + & + \\
Macrocephaly (OFC >97th centile) & - & - \\
Vertebral/rib anomalies observed on chest X-ray and/or spinal X-ray & - \\
Cleft lip/palate & + & - \\
Cardiac or ovarian fibroma & + \\
Childhood medulloblastoma & - \\
Preaxial or postaxial polydactyly & - \\
Ocular anomalies (cataract, developmental defects, coloboma) & - \\
Lympho-mesenteric or pleural cysts & - \\
\hline The proband is deceased at the age of 2 years after medulloblastoma surgery. Hence, some of his clinical features had not appeared at that \\
time. BCC, basal cell carcinoma; NBCCS, nevoid basal cell carcinoma syndrome. \\
\hline
\end{tabular}

